\title{
Contributing Factors of Time Overrun in Public Sector Construction Projects
}

\author{
Muhammad Akram Akhund \\ Department of Civil Engineering, \\ ISRA University, \\ Hyderabad, Pakistan \\ akhund42@gmail.com
}

\section{Fida Hussain Siddiqui}

Department of Civil Engineering, Mehran University of Engineering \& Technology, Jamshoro, Pakistan fida.siddiqui@faculty.muet.edu.pk

\author{
Hafiz Usama Imad \\ Department of Civil Engineering, \\ ISRA University, \\ Hyderabad, Pakistan \\ usama.imad@isra.edu.pk
}

\author{
Ali Raza Khoso \\ Department of Civil Engineering, \\ Mehran University of Engineering \& \\ Technology, Jamshoro, Pakistan \\ aliraza.khoso@faculty.muet.edu.pk
}

\author{
Nafees Ahmed Memon \\ Department of Civil Engineering, \\ Mehran University of Engineering \& \\ Technology, Jamshoro, Pakistan \\ nafees.memon@faculty.muet.edu.pk
}

\author{
Abbas Ali Panhwar \\ Sindh Irrigation Department, \\ Sindh, Pakistan \\ abbasalipanhwar@gmail.com
}

\begin{abstract}
Time overrun is a major issue in construction projects. Its causes vary, depending upon the nature and size of the project. Developing countries are more susceptible to this problem due to limited resources and lack of managerial skills. This paper focuses on the identification and classification of time overrun factors in public sector projects in Pakistan. Data was collected by the use of a questionnaire given to different professionals in the construction field. Average index (AI) was used to determine each factor's relative importance. Results indicate that financial difficulties faced by constructor, inadequate planning and scheduling, financial difficulties faced by client, delays in payment by the client, delays in decision making by the client, design mistakes, frequent design changes, material shortage, incompetent sub-constructor assigned by the constructor, poor site management and supervision and inadequate constructor's experience are the most significant factors of time overrun in public sector construction projects in Pakistan. This study aims to be useful in addressing the issue of time overrun in the construction industry.
\end{abstract}

Keywords-time overrun; construction industry; public sector

\section{INTRODUCTION}

In Pakistan, the construction industry is growing and contributing significantly to the economic growth of the country. Although Pakistan is spending a significant amount of money on the construction industry, still it faces several issues and serious challenges [1], with frequent project time overrun being one of the major ones. Project time overrun can be defined as the exceeding of project completion time from the anticipated and estimated duration of the project [2]. Time overrun in public sector construction projects is a global issue. This tendency is augmented in developing countries. In an estimate, time and cost overruns are about more than $100 \%$ of the estimated time and cost. [3-5]. It has been identified that due to poor risk management applications, time overrun is a common issue in construction projects [6-7]. It has an adverse effect on the owner, consultant and constructor in terms of relationships development, issue of cash flow, distrust, legal actions and a general feeling of unease toward one other.

\section{REASONS OF TIME OVERRUN}

Author in [1] presents the significances of schedule delay in construction. Authors in [8] determined 83 factors of time overrun in construction projects of Hong Kong. In Nigeria, 61 building construction projects were considered as a case study in [9], in which delay and budget overrun were found as the most responsible factors of time overrun. Authors in [10], conducted a research in Malaysian construction industry, and identified the effects and causes of delays: poor planning, contractor's poor site management, poor constructor experience, insufficient funds provided from client on the completed work, issues with sub-constructors, shortage of materials at site, equipment availability and failure, labor supply, mistakes during execution. Author in [11], studied the most common cases of time overrun in road construction projects in Palestine. Results revealed that the most significant common possible risks occur due to overrun factors such as constructor's financial status, delays in payment by the client, breakdown in the marketing shares of West Bank and political conditions, poor communication among construction stakeholders, poor equipment efficiency and high competition in bids. After the Egyptian revolution, a case study [12], highlighted 99 causative factors of time overrun. From determined causes, the top most ranked factors were poor funding, material bribes and tactics policies, equipment shortage at the construction site, poor project scheduling, poor financial control on site, poor site management and supervision, rework due to mistakes and errors, poor planning and inadequate constructors. 
Authors in [13] studied the schedule delay in construction projects of Gwalior, India. The most important factors causing time overrun was poor planning and scheduling, poor documentation work, delay in material delivery and poor work progress. Similarly, authors in [14] studied the causes and schedule delays in Indian construction projects. The findings of their research were: poor constructor's work and experience, poor risk management system, poor coordination and communication among client, constructor sub-constructor, consultant, designer, worker and supplier, delay in material delivery, poor planning and scheduling, poor supervision and site management, poor managerial skills, unqualified labor, delay in progressive payment, delay in sub-constructors work, change in orders from client and poor client's experience and involvement. Authors in [15] identified 12 major causes of delays in Nigerian construction industry. The construction sector in Bahrain is also facing the problem of time overrun which is caused by the shortage of manpower, poor communication between the stakeholder's, poor planning and scheduling, inexperienced personnel, poor supervision and site management, difficulties in project financing [4]. Authors in [16] investigated bridge construction projects of Pune and found insufficient crane capacity, unavailability of skilled labor, design issues, labor issues, conventional method of bar cutting and bending, delay in procurement of bearing plate, poor site layout resulting in poor labor productivity and shortage of concrete as major issues affecting project time. Authors in [17] conducted a questionnaire survey to determine the causes of time delay of road over bridge (ROB) in India. From the list of 29 different causes the study identified, the top 5 factors identified as responsible for causing time delay and cost overrun of ROB construction projects were land acquisition, many stakeholders, network displacement, legal requirements, and claims and disputes. Authors in [18] also conducted a questionnaire survey and personal interviews to analyze factors affecting scheduling performance in Ethiopian construction projects through the engineers' perspective. From the list of 35 time overrun attributes, they identified 4, namely: conflict among project participants, poor human resource management and project manager's ignorance and lack of knowledge which cause significant delay. Similarly, authors in [19], based on questionnaire survey identified the top 10 delay factors in Norwegian construction industry.

Most of the existing research has been carried out for private sector projects in different countries. No such research work has been reported regarding the public sector construction projects in Pakistan and this research fills this gap. This study will help the stakeholders of the industry to deal with project time overrun in upcoming projects. Hence, the purpose of this research is to identify the most significant factors of time overrun in public section construction projects in Pakistan. This research study identifies the common factors of time overrun which can be thought of and so anti measures can be planned in order to minimize cost overrun in public projects of Pakistan.

\section{DATA COLLECTION AND ANALYSIS}

Various reasons which contribute to time overrun in construction projects were identified from the literature review in the previous section. Among the list of identified factors responsible for time overrun, the related factors to Pakistan's construction industry were separated via a preliminary survey. As a part of the preliminary survey, unstructured interviews of constructors, consultants, clients, and experts were conducted to finalize factors. A questionnaire was then prepared for data collection. The finalized questionnaire was distributed among the experienced personnel involved in public sector construction projects of Pakistan. The respondents were asked to rank the significance of these factors on a Likert scale ranging from 1 (extremely significant) to 5 (not significant). The level of significance has been calculated with the statistical software package SPSS 20.0 through average index (AI) method [20, 21]. The AI obtained for each factor represents the importance or significance of the said factor as per given criteria:

$$
\begin{array}{ll}
4.50<\mathrm{AI}<5.00: & \text { Extremely significant (ES), } \\
3.50<\mathrm{AI}<4.50: & \text { Very significant (VS), } \\
2.50<\mathrm{AI}<3.50: & \text { Moderately significant (MS), } \\
1.50<\mathrm{AI}<2.50: & \text { Slightly significant (SS), } \\
1.00<\mathrm{AI}<1.50: & \text { Not significant (NS). }
\end{array}
$$

\section{RESULTS AND DISCUSSION}

One hundred and fifty questionnaires were distributed amongst practitioners who were selected randomly from clients, consultants, and constructors. Of these 150 questionnaires, 111 were returned completed. Data cleaning and data validation required a rejection of 6 questionnaires. Hence, a total number of 105 completed questionnaires were considered for data analysis. Figure 1 shows the summary of the data collection of the questionnaire survey.

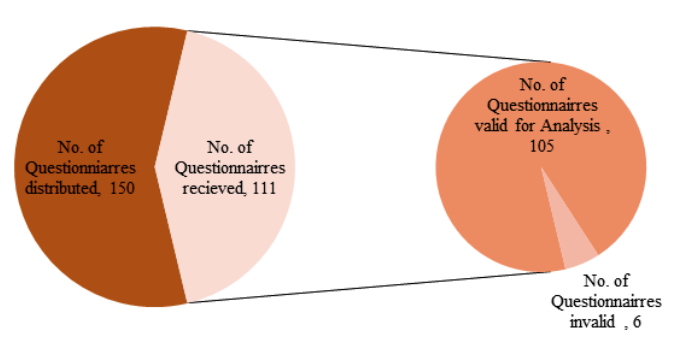

Fig. 1. Data collection summary

The demographic feature summary of respondents participated in data collection for this research is shown in Table I. The statistics regarding the correspondents' experience indicate that most of the respondents have good experience in handling public sector projects in Pakistan. 
TABLE I. DEMOGRAPHIC FEATURES OF RESPONDENTS

\begin{tabular}{|c|c|c|c|}
\hline & Frequency & Percentage & Cumulative \\
\hline \multicolumn{4}{|c|}{ Type of Organization } \\
\hline Client & 35 & 33.33 & 33.33 \\
\hline Consultant & 35 & 33.33 & 66.66 \\
\hline Constructor & 35 & 33.33 & 100.00 \\
\hline \multicolumn{4}{|c|}{ Type of Projects } \\
\hline Commercial & 12 & 11.40 & 11.40 \\
\hline Roads & 17 & 16.20 & 27.60 \\
\hline Residential & 28 & 26.70 & 57.30 \\
\hline Social Amenities & 10 & 9.50 & 63.80 \\
\hline Bridges & 9 & 8.60 & 72.40 \\
\hline Others & 29 & 27.60 & 100.00 \\
\hline \multicolumn{4}{|c|}{ Total Working Experience } \\
\hline 0-5 Years & 40 & 38.10 & 38.10 \\
\hline 5-10 Years & 25 & 23.80 & 61.90 \\
\hline 11-15 Years & 13 & 12.40 & 74.30 \\
\hline More than 15 Years & 27 & 25.70 & 100.00 \\
\hline \multicolumn{4}{|c|}{ Level of Position } \\
\hline Superintendent engineer & 4 & 03.80 & 03.80 \\
\hline Project manager & 9 & 08.57 & 12.37 \\
\hline Executive engineer & 15 & 14.28 & 26.65 \\
\hline Resident engineer & 9 & 08.57 & 35.22 \\
\hline Director & 3 & 02.86 & 38.08 \\
\hline Others & 65 & 61.90 & 100.00 \\
\hline
\end{tabular}

\section{A. Reliability Test Analysis}

Before data analysis, a reliability test was performed to check the degree of consistency of the collected data. Inner consistency was measured with the help of the Cronbach's $\alpha$ coefficient. For assessment of the reliability, the value of Cronbach's $\alpha$ in the range of $0.5-0.6$ is desirable, while if $\alpha$ is less than 0.3 , then the reliability is in low level and would not be accepted [7]. If Cronbach's $\alpha$ is more than 0.7, then the consistency index shows high reliability and it would be acceptable. Cronbach's $\alpha$ value for the collected data was found as 0.91 which is desirable and acceptable. The result of the reliability test confirmed the reliability of the collected questionnaire survey data which can be used for further analysis.

\section{B. Ranking of Time Overrun Reasons in Construction Projects}

Ranking of factors leading time overrun has been evaluated with the AI method. Table II depicts the results and highlights the significant ranking of each time overrun factor, their respective AI and standard deviations. The first four factors are described below.

\section{1) Financial Difficulties Faced by the Constructor}

Public sector construction project personnel ranked financial difficulties faced by the constructor as extremely significant factor of time overrun. The respondents consider this issue as the main cause in the delay of work execution as hindrances in finance even at the constructor side might delay or stop the work.

\section{2) Inadequate Planning and Scheduling}

The stakeholders ranked inadequate planning and scheduling as the second highest ranked factor of time overrun. Due to inadequate planning and scheduling, many other issues may be initiated. It might even lead to financial loss for the contractor and ultimately client too. The resolution of this problem can be in the form of hiring a good planner so that proper scheduling may become possible.

TABLE II. RANKING OF TIME OVERRUN FACTORS

\begin{tabular}{|c|c|c|c|c|c|c|c|c|}
\hline Factors & ES & VS & MS & SS & NS & AI & S.D & Rank \\
\hline $\begin{array}{l}\text { Financial difficulties faced by } \\
\text { constructor }\end{array}$ & 74 & 17 & 10 & 3 & 1 & 4.52 & 0.86 & 1 \\
\hline $\begin{array}{c}\text { Inadequate planning and } \\
\text { scheduling }\end{array}$ & 78 & 14 & 5 & 5 & 3 & 4.51 & 0.99 & 2 \\
\hline $\begin{array}{c}\text { Financial difficulties faced by } \\
\text { client }\end{array}$ & 39 & 31 & 24 & 7 & 4 & 3.90 & 1.10 & 3 \\
\hline Delays in payment by client & 42 & 27 & 23 & 9 & 4 & 3.90 & 1.14 & 4 \\
\hline $\begin{array}{c}\text { Delays in decision making by } \\
\text { client }\end{array}$ & 27 & 41 & 20 & 11 & 6 & 3.69 & 1.14 & 5 \\
\hline Design mistakes & 36 & 23 & 24 & 16 & 6 & 3.64 & 1.26 & 6 \\
\hline Frequent design changes & 28 & 31 & 25 & 16 & 5 & 3.58 & 1.17 & 7 \\
\hline Material shortage at site & 26 & 30 & 27 & 20 & 2 & 3.55 & 1.12 & 8 \\
\hline Incompetent subcontractor & 20 & 43 & 21 & 14 & 7 & 3.52 & 1.14 & 9 \\
\hline $\begin{array}{c}\text { Poor site management and } \\
\text { supervision }\end{array}$ & 26 & 26 & 35 & 12 & 6 & 3.51 & 1.15 & 10 \\
\hline $\begin{array}{c}\text { Inadequate constructor's } \\
\text { experience }\end{array}$ & 23 & 33 & 29 & 14 & 6 & 3.50 & 1.14 & 11 \\
\hline $\begin{array}{c}\text { Delays in contractor's } \\
\text { payment to subcontractor }\end{array}$ & 23 & 28 & 26 & 23 & 5 & 3.39 & 1.19 & 12 \\
\hline $\begin{array}{c}\text { Incomplete drawings provided } \\
\text { by consultant }\end{array}$ & 21 & 36 & 21 & 16 & 11 & 3.38 & 1.26 & 13 \\
\hline Excessive change in orders & 23 & 24 & 33 & 18 & 7 & 3.36 & 1.19 & 14 \\
\hline $\begin{array}{l}\text { Lack of coordination among } \\
\text { client, consultant and } \\
\text { constructor }\end{array}$ & 19 & 23 & 39 & 18 & 6 & 3.30 & 1.13 & 15 \\
\hline $\begin{array}{c}\text { Inadequate consultant's } \\
\text { experience }\end{array}$ & 19 & 28 & 31 & 19 & 8 & 3.30 & 1.18 & 15 \\
\hline Delay in material delivery & 18 & 31 & 26 & 22 & 8 & 3.28 & 1.20 & 16 \\
\hline Shortage of skilled labour & 15 & 33 & 28 & 24 & 5 & 3.28 & 1.11 & 16 \\
\hline Shortage of equipment & 15 & 28 & 31 & 28 & 3 & 3.23 & 1.09 & 17 \\
\hline Poor labour productivity & 14 & 28 & 37 & 19 & 7 & 3.22 & 0.88 & 18 \\
\hline Mistakes during construction & 16 & 25 & 33 & 24 & 7 & 3.18 & 0.87 & 19 \\
\hline Change in the project scope & 18 & 29 & 24 & 21 & 13 & 3.17 & 0.87 & 20 \\
\hline $\begin{array}{l}\text { Lack of communication } \\
\text { among client, consultant and } \\
\text { constructor }\end{array}$ & 16 & 19 & 44 & 18 & 8 & 3.16 & 0.87 & 21 \\
\hline Fluctuation in material prices & 17 & 22 & 34 & 23 & 9 & 3.14 & 0.87 & 22 \\
\hline $\begin{array}{l}\text { Improper construction } \\
\text { methods }\end{array}$ & 11 & 28 & 38 & 20 & 8 & 3.13 & 0.87 & 23 \\
\hline Insufficient equipment & 15 & 23 & 33 & 29 & 5 & 3.13 & 0.87 & 23 \\
\hline Contractual claims & 8 & 33 & 32 & 24 & 8 & 3.09 & 0.86 & 24 \\
\hline $\begin{array}{l}\text { Inspection delays of site by } \\
\text { consultant }\end{array}$ & 11 & 30 & 28 & 25 & 11 & 3.05 & 0.86 & 25 \\
\hline Complex design of project & 10 & 25 & 41 & 16 & 13 & 3.03 & 0.85 & 26 \\
\hline Rework due to poor quality & 11 & 26 & 28 & 26 & 14 & 2.94 & 0.86 & 27 \\
\hline Excessive bureaucracy & 10 & 29 & 28 & 19 & 19 & 2.92 & 0.86 & 28 \\
\hline $\begin{array}{c}\text { Changes in material } \\
\text { specifications }\end{array}$ & 11 & 22 & 28 & 32 & 12 & 2.89 & 0.86 & 29 \\
\hline $\begin{array}{c}\text { Changes in rules and } \\
\text { regulations }\end{array}$ & 14 & 21 & 25 & 27 & 18 & 2.87 & 0.87 & 30 \\
\hline Unforeseen ground conditions & 9 & 19 & 29 & 36 & 12 & 2.78 & 0.88 & 31 \\
\hline Bad weather & 14 & 10 & 21 & 36 & 24 & 2.56 & 0.91 & 32 \\
\hline Accidents on site & 14 & 9 & 21 & 37 & 24 & 2.54 & 0.91 & 33 \\
\hline
\end{tabular}

3) Financial Difficulties Faced by the Client

The third highest cause affecting the estimated time of construction project completion, was financial difficulties faced by the client. If the owner party wants to complete the projects on time with the specific requirements then a system must be generated by the owner's party to resolve this issue. 


\section{4) Delay in Decision Making by the Client}

Like other significant factors of time overrun, delay in decision making by the client is the fourth highest ranked factor by public sector construction personnel, which means it is quite a significant factor affecting construction projects completion time. This issue seems to be highly related to the financial difficulties faced by the constructor, inadequate planning, and scheduling, financial difficulties faced by the client and delays in payment by the client.

\section{CONCLUSION}

This paper focused on uncovering factors of time overrun in public sector construction projects in Pakistan. Extensive literature review was carried out which helped in structuring the questionnaire for data collection. Statistical analysis results of the questionnaire survey shown in Table II ranked financial difficulties faced by the constructor, inadequate planning and scheduling, financial difficulties faced by the client and delays in payment by the client, as the most significant factors of time overrun. Identified factors will help stakeholders to plan accordingly in order to avoid the issue of time overrun.

\section{REFERENCES}

[1] D. M. Leishman, "Protecting engineer against construction delay claims NDC", Journal of Management in Engineering, Vol. 7, No. 3, pp. 314-333, 1991

[2] A. U. Elinwa, M. Joshua, "Time-overrun factors in the Nigerian construction industry", Journal of Construction Engineering and Management, Vol. 127, No. 5, pp. 419-425, 2001

[3] M. Abd El-Razek, H. Bassioni, A. Mobarak, "Causes of Delay in Building Construction: Projects in Egypt", Journal of Construction Engineering And Management, Vol. 134, No. 11, pp. 831-841, 2008

[4] R. Hassan, A. M. S. Suliman, A. Y. Malki, "An Investigation into the Delays in Road Projects in Bahrain", International Journal of Research in Engineering and Science, Vol. 2, No. 2, pp. 38-47, 2014

[5] E. G. Sinesilassie, S. Z. S. Tabish, K. N. Jha, "Critical factors affecting schedule performance: A case of Ethiopian public construction projects-engineers' perspective", Engineering, Construction and Architectural Management, Vol. 24, No. 5, pp. 757773,2017

[6] N. Ejaz, I. Ali, M. F. Tahir, "Assessment of delays and cost overruns during construction projects in Pakistan", available at: http://dl.lib.mrt.ac.lk/handle/123/9431, 2013

[7] S. Meepol, S. O. Ogunlana, "Factors affecting cost and time performance on highway construction projects: evidence from Thailand", Journal of Financial Management of Property and Construction, Vol. 11, No. 1, pp. 3-20, 2006

[8] D. W. Chan, M. M. Kumaraswamy, "A Comparative Study of Causes of Time Overruns in Hong Kong Construction Projects", International Journal of Project Management, Vol. 15, pp. 55-63, 1997

[9] A. A. Aibinu, G. O. Jagboro, "The effects of Construction Delays on Project Delivery in the Nigerian Construction Industry", International Journal of Project Management, Vol. 20, pp. 593-599, 2002

[10] M. Sambasivan, Y. W. Soon, "Causes and Effects of Delays in Malaysian Construction Industry", International Journal of Project Management, Vol. 25, pp. 517-526, 2007

[11] I. Mohammid "Common risks affecting time overrun in road construction projects in Palestine: Contractors' perspective", Australasian Journal of Construction Economics and Building, Vol. 13, No. 2, pp. 45-53, 2013
[12] R. F. Aziz, "Ranking of Delay Factors in Construction Projects After the Egyptian Revolution", Alexandria Engineering Journal, Vol. 52, pp. 387-406, 2013

[13] A. Upadhyay, V. Gupta, M. Pandey, "A case study on schedule delay analysis in construction projects in Gwalior", International Research Journal of Engineering and Technology, Vol. 3, No. 5, pp. 13121315,2016

[14] D. Kumar, "Causes and Effects of Delays in Indian Construction Projects", International Research Journal of Engineering and Technology, Vol. 3, No. 4, pp. 1831-1837, 2016

[15] M. Murray, M. Seif, "Causes of project delays in the Nigerian construction industry", European Journal of Civil Engineering and Architecture, Vol. 10, pp. 1-7, 2013

[16] J. K. Shah, R. M. Apte, "Causes of Delay in Construction of Bridge Girders", Journal of Mechanical and Civil Engineering, Vol. 12, No. 1,pp. 8-12, 2015

[17] C. B. Venkateswaran, R. Murugasan, "Time Delay and Cost Overrun of Road over Bridge (ROB) Construction Projects in India", Journal of Construction in Developing Countries, Vol. 22, pp. 79-96, 2017

[18] E. G. Sinesilassie, S. Z. S., Tabish, K. N. Jha, "Critical factors affecting schedule performance: A case of Ethiopian public construction projects-engineers' perspective", Engineering, Construction and Architectural Management, Vol. 24, No. 5, pp. $757-$ 773,2017

[19] Y. J. T. Zidane, B. Andersen, "The top 10 universal delay factors in construction projects", International Journal of Managing Projects in Business, Vol. 11, No. 3, pp. 650-672, 2018

[20] M. A. Akhund, A. R. Khoso, U. Memon, S. H. Khahro, "Time Overrun in Construction Projects of Developing Countries", Imperial Journal of Interdisciplinary Research, Vol. 3, No. 5, pp. 124-129, 2017

[21] M. Akram, T. H. Ali, N. A. Memon, S. H. Khahro, "Causal Attributes of Cost Overrun In Construction Projects of Pakistan", International Journal of Civil Engineering and Technology, Vol. 8, No. 6, pp. $477-$ 483,2017 